\title{
POLA KONSUMSI: LITERASI EKONOMI, STATUS SOSIAL ORANG TUA DAN TEMAN SEBAYA
}

\author{
Filomina Nurjaya Onis \\ e-mail: filominanurjaya11@yahoo.com \\ Lilik Sri Hariani \\ e-mail: liliksrihariani@unikama.ac.id \\ Ninik Indawati \\ e-mail: ninikberty@unikama.ac.id
}

(Program Studi Pendidikan Ekonomi, Fakultas Ekonomika dan Bisnis, Universitas Kanjuruhan, Malang)

\begin{abstract}
Consumption patterns can be influenced by the external factors and internal students. Several factors such as economic literacy, social statues parents, and the peers. Assuming that someone who has economic literacy tend to patterned consumption by smart which is to pattern of behavior rational, but economic literacy, social statues parents are very significant impact on consumption patterns, but those two factors group their peers also influences pattern of behavior consumption. This research intend to know influence in a partial and simultaneous between economic literacy, social statues parents and group their peers against consumption patterns graders XI social class high school of National Malang. This research uses the quantitative sample with the national high school students poor were 61 students data collection in this research that is using the survey, tests, interviews and documentation.
\end{abstract}

Keywords : Economic literacy, Social status parents, The peers, Consumption patterns

\begin{abstract}
Abstrak: Pola konsumsi dapat dipengaruhi oleh adanya faktor eksternal dan internal siswa. Beberapa faktor tersebut diantaranya yakni literasi ekonomi, status sosial orang tua, dan kelompok teman sebaya. Dengan asumsi bahwa Seseorang yang memiliki literasi ekonomi cenderung berpola konsumsi dengan cerdas yang berarti lebih ke pola perilaku yang rasional, selain literasi ekonomi, status sosial orang tua juga sangat berpengaruh terhadap pola konsumsi, selain kedua faktor tersebut kelompok teman sebaya juga berpengaruh terhadap pola perilaku konsumsi. Penelitian ini bermaksud untuk mengetahui pengaruh secara parsial dan simultan antara literasi ekonomi, status sosial orang tua dan kelompok teman sebaya terhadap pola konsumsi siswa Kelas XI IPS SMA Nasional Malang. Penelitian ini menggunakan metode kuantitatif dengan Sampel seluruh siswa SMA Nasional malang yang berjumlah 61 siswa. Adapun tekhnik pengumpulan data dalam penelitian ini yaitu menggunakan angket, tes, wawancara dan dokumentasi. Tekhnik analisis menggunakan Uji asumsi klasik, uji regresi linear berganda dan uji hipotesis. Hasil penelitian menunjukan hasil penelitiann (1) ada pengaruh secara simultan yang signifikan literasi ekonomi, status sosial orang tua, dan kelompok teman sebaya terhadap pola konsumsi siswa (2) ada pengaruh secara parsial yang signifikan literasi ekonomi terhadap pola konsumsi siswa (3) ada pengaruh secara parsial yang signifikan status sosial orang tua terhadap pola konsumsi siswa (4) ada pengaruh secara parsial yang signifikan teman terhadap pola konsumsi siswa.
\end{abstract}

Kata kunci : Brand Image Kampus, Kondisi Sosial Ekonomi Orang Tua, Tingkat Kemampuan Akademik, Minat Melanjutkan Ke Perguruan Tinggi 


\section{PENDAHULUAN}

Perkembangan dan kemajuan jaman telah menciptakan beraneka macam kebutuhan manusia. Karakterisktik kebutuhan manusia dalam analisis ekonomi adalah bahwa kebutuhan manusia tidak terbatas dan setiap manusia memiliki kecendrungan untuk memenuhinya. Sumber daya yang tersedia yang untuk memenuhi kebutuhan manusia yang tidak terbatas itu sangat langka. Permasalahan inilah yang menjadi penghalang manusia dalam mencapai tujuan hidupnya. Manusia terkadang tidak menyadari keterbatasan pendapatan yang dimilikinya sehingga berakibat pola konsumsi manusia tidak rasional. Pola konsumsi yang tidak rasional ini tidak hanya dialami oleh manusia dewasa namun juga terjadi pada aktivitas ekonomi siswa SMA khususnya dalam melakukan tindakan konsumsinya. Seperti yang terjadi pada cara berkonsumsi siswa SMA Nasional Malang masih kurang efektif dan efisien. Hal ini menunjukan pada cara siswa dalam menggunakan uang sakunya. Penggunaan uang saku mereka lebih digunakan untuk keinginan atau kesenangan dan tidak bermanfaat untuk kebutuhan. Misalnya menghabiskan uang saku sebagian besar untuk berbelanja ke mall, pergi ke restoran maupun kafe di lingkungan sekitarnya yang menyediakan berbagai tempat perbelanjaan, aneka kuliner, maupun sarana hiburan Mangkunegara (2009:11) mengatakan faktor-faktor yang mempengaruhi pola konsumsi yaitu kekuatan sosial budaya(faktor Budaya, tingkat sosial, kelompok anutan dan keluarga) dan faktor kekuatan psikologis (pengalaman belajar, kepribadian, sikap, dan keyakinan serta gambaran diri)". Dalam hal ini peneliti mengambil 3 variabel dari beberapa faktor diatas yaitu faktor pengalaman belajar (Literasi Ekonomi/ Pemahaman dasar ekonomi), faktor keluarga (Status sosial orang tua), dan faktor kelompok anutan (Kelompok Teman Sebaya).

Literasi ekonomi sebagai salah satu aspek penting dalam kehidupan manusia dimana melek ekonomi atau pemahaman ekonomi memiliki peran penting dalam membentuk sikap rasional berkonsumsi. Literasi ekonomi dapat membuat seseorang menjadi cerdas dalam mengelolah sumber daya ekonomi untuk mencapai kesejahteraaan dengan cara mengaplikasikan konsep tersebut. Selain itu, literasi ekonomi menjadi sangat penting untuk membuka pengetahuan tentang biaya manfaat suatu barang dalam aktivitas ekonomi. Selain itu, salah satu wujud antisipasi yang paling berpengaruh terhadap pola konsumsi siswa yakni status yang dimiliki orang tua. Status sosial yang dimiliki orang tua turut mendukung dan mendorong bahkan dapat mengacu siswa dalam pola perilaku konsumsinya, misalnya orang tua yang memiliki status sosial yang tinggi biasanya berbeda bentuk cara berkonsumsi dengan orang tua yang memiliki status sosial yang rendah, seperti dalam memenuhi kebutuhan, mereka yang memiliki status sosial yang tinggi, kebutuhannya selalu terpenuhi ketimbang mereka yang memiliki status sosial yang rendah. Selain literasi ekonomi dan status sosial orang tua, kelompok teman sebaya juga dapat mempengaruhi pola konsumsi siswa. Schiffman dan Kanuk, Peter dan Olson (2010) menyatakan bahwa selain ibu dan ayah, keputusan pembelian pada anak-anak dan orang dewasa keduanya sangat dipengaruhi oleh teman Sebaya. Emosi remaja yang masih tidak stabil dan cendrung berpengaruh terhadap semua hal yang berkaitan dengan pribadinya dan permasalahan dirinya sehingga membuat remaja seringkali bertindak kurang rasional dalam pola prilaku konsumsinya.

Berdasarkan latar belakang masalah yang telah dipaparkan diatas maka mendorong penulis untuk mengangkat permasalahan tersebut dengan judul "Pengaruh Literasi Ekonomi, Status Sosial Orang Tua, dan Kelompok Teman Sebaya Terhadap Pola Konsumsi Siswa". Tujuan penelitian ini adalah : 1) Untuk menganalisis pengaruh secara simultan antara literasi ekonomi, status sosial 
ekonomi orang tua dan kelompok teman sebaya terhadap pola konsumsi pada siswa kelas XI SMA Nasional Malang, 2) Untuk menganalisis pengaruh literasi ekonomi terhadap pola konsumsi pada siswa kelas XI SMA Nasional Malang, 3) Untuk menganalisis pengaruh status sosial ekonomi orang tua terhadap pola konsumsi pada siswa kelas XI SMA Nasional Malang?, 4) Untuk menganalisis pengaruh kelompok teman sebaya terhadap pola konsumsi pada siswa kelas XI SMA SMA Nasional Malang?.

\section{TINJAUAN PUSTAKA}

Menurut Alam (2013:46) dalam ilmu ekonomi, "konsumsi adalah suatu kegiatan yang bertujuan mengurangi atau menghabiskan faedah suatu benda (barang dan jasa) dalam rangka memenuhi kebutuhan". Dalam kehidupan sehari-hari konsumsi identik dengan kegiatan makan dan minum. Manusia berkeinginan makan karena makan akan sangat dibutuhkan jasmani. Pola konsumsi diartikan sebagai suatu bentuk atau struktur tindakan seseorang dalam memanfaakan, mengurangi, bahkan menghabiskan nilai guna barang maupun jasa untuk memenuhi kebutuhannya. Pola konsumsi merupakan berbagai informasi yang memeberi gambaran mengenai macam dan jumlah bahan makanan yang dimakan setiap hari oleh seseorang yang merupakan ciri khas suatu kelompok siswa (Lie Goan Hong, 2004) dalam yulia (2010:23). Pola konsumsi juga dapat diartikan sebagai tanggapan aktif manusia terhadap lingkungan alam maupun lingkungan sosial. Menurut Prasetyo (2013) mengungkapkan indikator pola konsumsi 1) efisiensi konsumsi (pemenuhan kebutuhan sesuai dengan tingkat kebutuhan, penerapan prinsip-prinsip ekonomi dalam berkonsumsi, besar pengeluaran untuk berkonsumsi dan ragam barang dan jasa yang di konsumsi), 2) motif konsumsi(pengaruh lingkungan sosial pada aktifitas berkonsumsi, keterkaitan dengan iklan, keinginan menabung, motif berkonsumsi)

Literasi dalam arti luas adalah melek teknologi, politik, ekonomi, berpikir kritis dan peka terhadap lingkungan sekitar, seperti yang dikatakan Peter Sina (2013:135) "Literasi Ekonomi merupakan alat yang berguna untuk merubah perilaku dari tidak cerdas menjadi cerdas". Seperti bagaimana memanfaatkan pendapatan untuk menabung, berinvestasi, proteksi dan memenuhi kebutuhan. Menurut pendapat Caplan dalam Januar Kustiandi (2011) yang menyatakan bahwa literasi ekonomi merupakan pengetahuan tentang ekonomi yang hal ini sangat diperlukan karena setiap kegiatan manusia tidak terlepas dari masalah ekonomi. Masalah-masalah ekonomi ini berkaitan dengan bagaimana seseorang dapat memanfaatkan keterbatasan sumber daya yang dimiliki untuk dapat menentukan pilihan alternatif pemecahan masalah yang tepat dalam memenuhi kebutuhan hidupnya, dengan mempertimbangkan antara pengorbanan biaya dengan hasil (manfaat) yang akan diperoleh. Hal ini sejalan dengan pendapat Haryono (2008) bahwa literasi ekonomi adalah kemampuan untuk mengidentifikasi masalah-masalah ekonomi, penyusunanan alternatif pemecahan dengan mempertimbangkan benefit dan cost. Peter Sina (2013) mengatakan bahwa literasi ekonomi merupakan pemahaman seseorang yang terkristalkan dalam membuat pilihan yang cerdas terkait alokasi sumber daya. Negara Amerika sosialisasi literasi ekonomi dilakukan oleh NCCE (The National Counsil on Ekonomic Educaton). dalam Haryono (2008:29-30) 1) mampu menganalisis perubahan permintaan barang, 2) mampu menganalisis perubaahan penawaran dan permintaan, 3) menjelaskan pendapatan individu, 4) mampu menjelaskan peran pelaku ekonomi, 5) mampu menganalisis dampak perubahan permintaan terhadap harga barang, 6) mampu menjelaskan 
penggunaan sumber daya yang terbatas, dan 7) mampu menjelaskan peran pasar modal dalam perekonomian.

Status sosial orang tua merupakan merupakan suatu kedudukan sosial atau posisisi orang tua disuatu masyarakat yang berpengaruh terhadap pola perilaku anaknya. Poerwo darminto (2008:688) mengatakan orang tua berarti ibu dan ayah kandung, orang yang dianggap tua, (pandai dan cerdik). Menurut Hasan (2014:164) “Keluarga merupakan organisasi kecil yang penting dalam mempengaruhi perilaku anggotanya yang bersumber dari orang tua". Suami, istri, dan anak memiliki peran yang berbeda dalam mempengaruhi perilaku pembelian mereka.

Status sosial menurut Sumarwan (2011:265) "disamakan dengan kelas sosial, yaitu pembagian masyarakat ke dalam kelas-kelas yang berbeda atau strata yang berbeda." Sedangkan Sukanto (2012:210) mendefinisikan status sosial atau disebut juga kedudukan sosial adalah " tempat seseorang secara umum dalam masyarakatnya sehubungan dengan orang-orang lain, dalam arti lingkungan pergaulannya, prestisenya, dan hak-hak serta kewajiban-kewajibannya". Menurut Soekanto (2014:262) dalam mengukur status sosial seseorang dimasyarakat, biasanya dipakai penggolongan-penggolongan tertentu, yaitu 1) ukuran kekayaaan, 2) ukuran kekuasaan, 3) ukurang kehormaratan, dan 4) ukuran ilme pengetahuan.

Pengaruh relatif sesudah keluarga, teman-teman yang paling mungkin mempengaruhi keputusan pembelian individu. Schiffman dan Kanuk, Peter dan Olson (2010) menyatakan bahwa selain ibu dan ayah, keputusan pembelian pada anak-anak dan orang dewasa keduanya sangat dipengaruhi oleh teman sebaya. Pendapat dan pilihan teman-teman merupakan pengaruh yang penting dalam menentukan produk atau merk yang akhirnya dipilih konsumen. Menurut Hetherington dan Parke dalam Desmita (2010:145) “ Teman sebaya sebagai kelompok sosial didefinisikan sebagai semua orang yang memiliki kesamaan sosial atau yang memiliki kesamaan ciriciri, seperti kesamaan tingkat usia dan tingkat kedwasaan yang sama". Menurut Mappiare dalam Murisal (2012:209), kelompok teman sebaya merupakan kelompok remaja dimana untuk pertama kalinya remaja tersebut menerapkan prinsip-prinsip hidup besama dan bekerja sama, dalam jalinan yang kuat tersebut terbentuk norma, nilai-nilai dan simbol. Hanifah (2015:21) indikator lingkungan teman sebaya terdiri dari 1) interaksi sosial teman sebaya, 2) keterlibatan individu dalam berinteraksi, 3) dukungan teman sebaya, dan 4) keintiman atau kasih saling antar teman sebaya.

Kajian empirik yang digunakan dalam penelitian ini adalah 1) Ria Anggella Prasetyo (2013) tentang pengaruh status sosial ekonomi dan literasi ekonomi, terhadap pola konsumsi siswa kelas XI IPS SMA Negeri 1 Talun Blitar" 2) Romdan Kurniawan (2014) tentang "pengaruh status sosial ekonomi orang tua dan pemahaman ekonomi terhadap pola konsumsi siswa kelas XI IPS SMA Negeri 1 Batu" 3) Rika Pristian Fitri Astuti (2016) tentang "pengaruh status sosial ekonomi orang tua dan literasi ekonomi terhadap perilaku konsumsi mahasiswa jurusan pendidikan ekonomi IKIP PGRI Bojonegoro" 4) Riza Yonisa Kurniawan (2016) tentang "pengaruh status sosial ekonomi orang tua dan literasi ekonomi terhadap perilaku konsumsi siswa kelas X IPS di SMA Negeri 2 Tuban" 5) Yayah Bahjatussaniah (2017) tentang "pengaruh status sosial ekonomi orang tua dan kelompok teman sebaya terhadap perilaku konsumsi siswa"

Pola konsumsi adalah kecendrungan sesorang untuk menghabiskan nilai guna suatu barang. Pola konsumsi diartikan sebagai suatu bentuk atau struktur tindakan seseorang dalam memanfaakan, mengurangi, bahkan menghabiskan nilai guna barang maupun jasa untuk memenuhi kebutuhannya. Pola Konsumsi dapat dipengaruhi oleh beberapa faktor. Faktor-faktor yang mempengaruhi pola 
konsumsi siswa diantaranya yaitu literasi ekonomi, status sosial orang tuua dan kelompok teman sebaya. Dengan pengansumsian bahwa literasi ekonomi dalam mempengaruhi pola konsumsi yaitu untuk membuat keputusn bagaimana berinvestasi yang tepat dan berpola konsumsi yang cerdas dengan memikirkan untuk lebih mementingkan kebutuhan rasional, selain literasi, status sosial orang tua juga dapat mempengaruhi pola konsumsi misalnya dalam memberi uang jajan yang berlebihan terhadap anaknya. Faktor lain yang mempengaruhi pola konsumsi yaitu Kelompok teman sebaya. Suatu kelompok (Group) biasanya melakukan suatu hal secara bersama-sama misalnya dalam membeli jajan secara bersama-sama, pergi belanja ke mall juga bahkan bersama-sama.

\section{METODE}

Penelitian ini menggunakan pendekatan kuantitatif dengan menggunakan analisis regresi berganda. Desain penelitian ini adalah kausal yang berguna untuk menganalisis hubungan antara variabel satu dengan variabel lainnya atau bagaimana suatu variabel mempengaruhi variabel lainnya. Populasi dalam penelitian ini adalah siswa kelas XI IPS SMA Nasional Malang dengan jumlah 61 siswa. Teknik pengambilan sampel dalam penelitian ini menggunakan sampel jenuh dikarenakan julah populasinya kurang dari 100 maka seluruh sampel digunakan untuk penelitian. Sedangkan metode yang digunakan dengan menggunakan metode analisis diskriptif dan analisis regresi. Teknik analisis data yang digunakan adalah kuantitatif deskriptif dan regresi berganda. Analisis kuantitatif deskriptif digunakan untuk mengetahui mean dari masing-masing variabel penelitian. Sedangkan analisis regresi berganda digunakan untuk mengetahui besarnya hubungan antara variabel bebas dan terikat baik secara parsial maupun secara simultan. Instrumen yang digunakan dalam penelitian ini yaitu menggunakan coesioner dan test. Cesioner digunakan untuk pengambilaan data varibel status sosial orang tua, kelompok teman sebaya dan pola konsumsi sedangkan test digunkan untuk pengambilan data variabel literasi ekonomi dengan bantuan SPSS versi 22.00 for windows.

\section{HASIL DAN PEMBAHASAN}

Pengaruh Literasi Ekonomi, Status Sosial Orang Tua dan Kelompok Teman Sebaya Terhadap Pola Konsumsi Siswa

Berdasarkan hasil uji F menunujukan Fhitung sebesar 7,375 dengan nilai signifikan 0,000. Karena tingkat signifikannya lebih kecil dari 0,05 maka ada pengaruh yang signifikan secara simultan literasi ekonomi, status sosial orang tua, dan kelompok teman sebaya terhadap pola konsumsi yang berarti bahwa tinggi rendahnya literasi ekonomi, status sosial orang tua dan kelompok teman sebaya akan berpengaruh terhadap tinggi rendahnya pola konsumsi siswa kelas XI SMA Nasional Malang.

Konsumsi identik dengan kegiatan makan dan minum dalam kehidupan sehari-hari. Manusia berkeinginan makan karena makan akan sangat dibutuhkan jasmani. Pola konsumsi yaitu kegiatan menghabiskan barang atau jasa Pola konsumsi siswa harus cendrung pada pola konsumsi yang rasioanal. Konsumsi yang rasioanal dalam artiannya pola konsumsi yang lebih mementingkan kebutuhan dari pada keinginian. Konsumsi yang rasioanal ini dapat dipengaruhi oleh beberapa faktor yaitu literasi ekonomi, status sosial orang tua, dan kelompok teman sebaya.

\section{Pengaruh Literasi Ekonomi Terhadap Pola Konsumsi Siswa}

Berdasarkan hasil uji t menunjukan t-hitung pada variabel literasi ekonomi memiliki nilai 3,244 dengan nilai signifikan 0,002. Karena tingkat signifikan lebih kecil dari 0,005 maka variabel X1 
literasi ekonomi berpengaruh terhadap pola konsumsi sehingga Ha2 diterima dan Ho2 ditolak. Hasil uji $\mathrm{t}$ diatas dapat menjadi acuan bahwa literasi ekonomi berpengaruh negatif terhadap pola konsumsi. Hal ini mengandung arti bahwa literasi ekonomi mempununyai pengaruh berbanding terbalik, karena koefisien regresinya negatif yang berarti bahwa siswa SMA Nasional melakukan konsumsi lebih mempertimbangkan keinginan dari pada kebutuhan, sehingga dapat disimpulkan terdapat pengaruh yang negatif dan signifikan secara parsial antara literasi ekonomi terhadap pola konsumsi dengan indikator yang terdiri dari mampu menganalisis perubahan permintaan barang, mampu mengalisis perubahan penawaran dan permintaan, menjelaskan pendapatan individu, mampu menjelaskan peran pelaku ekonomi, mampu menganalisis dampak perubahan permintaan terhadap harga barang, mampu menjelaskan penggunaan sumberdaya yang terbatas dan mampu mampu menjelaskan peran pasar modal dalam perkonomian.

Hasil penelitian ini sejalan dengan penelitian yang dilakukan oleh: Widia Dwiningsari yang berjudul pengaruh literasi ekonomi siswa, status sosial ekonomi orang tua dan dan konformitas kelompok teman sebaya terhdap pola konsumsi siswa kelas XI IPS SMA Brawijaya Smart School dengan hasil penelitian bahwa ada pengaruh yang signifikan antara literasi ekonomi terhadap pola konsumsi siswa SMA Brawijaya Smart School dalam arti bahwa semakin tinggi pengetahuan atau pemahaman ekonomi siswa maka konsumsi siswa akan cendrung lebih ke pola konsumsi yang rasional.

Literasi ekonomi sebagai sutu pemahaman dasar yang sangat diperlukan dalam kehidupan manusia karena manusia tidak terlepas dari masalah ekonomi. Literasi ekonomi yang tinggi seharusnya mempengaruhi bagaimana siswa berkonsumsi. Siswa yang mempunyai literasi ekonomi tinggi semestinya bersikap rasional dalam berkonsumsi. Kegunaan dan kepraktikan dari hasil pengajaran penting artinya, agar siswa dapat memecahkan persoalan yang dihadapinya baik disekolah ataupun dikehidupan sehari-hari, dimasyarakat dan dikeluarganya.

\section{Pengaruh Status Sosial Orang Tua Terhadap Pola Konsumsi Siswa}

Berdasarkan hasil uji t menunjukan t-hitung pada variabel status sosial orang tua (X2) memiliki ninlai $-3,048$ dengan nilai signifikan 0,003. Karena tingkat signifikan lebih kecil dari 0,005 maka variabel X2 (status sosial orang tua) berpengaruh terhadap Y (pola konsumsi) sehingga Ha2 diterima dan Ho2 ditolak. Hasil uji $t$ diatas dapat menjadi acuan bahwa status sosial orang tua berpengaruh negatif terhadap Y yaitu pola konsumsi. Hal ini mengandung arti bahwa status sosial orang tua (X2) mempununyai pengaruh berbanding terbalik dengan pola konsumsi ( $\mathrm{Y}$ ) yang berarti semakin status yang dimiliki orang tua maka pola konsumsi siswa juga ikut meningkat, sehingga dapat disimpulkan bahwa terdapat pengaruh yang signifikan secara parsial antara status sosial orang tua terhadap pola konsumsi dengan indikator yang terdiri dari ukuran kekayaan, ukuran kekuasaan, ukuran kehormatan dan ukuran ilmu.

Hasil penelitian ini sejalan dengan penelitian yang dilakukan oleh Romdan Kurniawan (2013) dengan judul pengaruh status sosial ekonomi orang tua, gaya hidup, dan pemahaman ekonomi dan perhatian orang tua terhadap pola konsumsi siswa Kelas XI IPS SMA Negeri 1 Batu dengan hasil penelitian terdapat pengaruh yang positif antara status sosial ekonomi orang tua terhadap pola konsumsi siswa, artinya semakin tinggi tatus sosial ekonomi yang dimiliki orang tua maka pola konsumsi anaknya juga ikut meningkat.

Status sosial orang memiliki makna atau mempunyai pengaruh tertentu terhadap individuindividu tertentu termasuk mempengaruhi pola perilaku konsumsi anaknya. Status sosial yang 
dimiliki orang tua turut mendukung dan mendorong bahkan dapat mengacu siswa dalam pola perilaku konsumsinya, misalnya orang tua yang memiliki status sosial yang tinggi biasanya berbeda bentuk cara berkonsumsi dengan orang tua yang memiliki status sosial yang rendah, seperti dalam memenuhi kebutuhannya, siswa atau anak-anak yang memiliki status sosial yang tinggi biasanya kebutuhannya selalu terpenuhi ketimbang siswa atau anak-anak yang memiliki status sosial yang rendah.

\section{Pengaruh Kelompok Teman Sebaya Terhdap Pola Konsumsi Siswa.}

Berdasarkan hasil uji t menunjukan t-hitung pada kelompok teman sebaya (X3) memiliki ninlai 3,487 dengan nilai signifikan 0,001. Karena tingkat signifikan lebih kecil dari 0,005 maka variabel X3 (kelompok teman sebaya) berpengaruh terhadap Y (pola konsumsi) sehingga Ha2 diterima dan Ho2 ditolak. Hasil uji t diatas dapat menjadi acuan bahwa kelompok teman sebaya berpengaruh yang signifikan terhadap $\mathrm{Y}$ yaitu pola konsumsi. Berdasarkan hasil analisis uji $t$, dikatakan bahwa terdapat pengaruh yang signifikan secara parsial antara kelompok teman sebaya terhadap pola konsumsi dengan indikator yang terdiri dari interaksi sosial teman sebaya, keterlibatan individu dalam berinteraksi, dukungan teman sebaya, keintiman atau sayang antar teman sebaya.

Hasil penelitian ini sejalan dengan penelitian yang dilakukan oleh Kiki Winaryo (2017) yang berjudul Pengaruh Status Sosial Ekonomi Dan Kelompok Teman Sebaya Terhadap Perilaku Konsumsi Siswa Kelas XI IPS di SMA N 1 Rembang Purbalingga dengan hasil penelitian Terdapat pengaruh positif dan signifikan kelompok teman sebaya terhadap perilaku konsumsi siswa kelas XI IPS di SMA N 1 Rembang Purbalingga, artinya bahwa semakin tinggi aktifitas siswa dengan kelompok teman sebayanya maka akan menyebabkan siswa mengikuti kelompok apa yang dilakukan teman-temannya termasuk membelanjakan segala kebutuhannya.

Kelompok teman sebaya terdiri atas jumlah individu yang sama. Pengertian sama disini berarti individu-individu anggota kelompok sebaya itu mempunyai dalam berbagai aspeknya. Persamaan yang penting terutama terdiri atas persamaan sosial dan status sosialnya. Kelompok teman sebaya sangat penting manfaatnya bagi remaja misalnya mereka bekerja sama mencapai tujuan dan mendapatkan penghargaan dan kepuasan dalm hasil interaksi sosial dan kerja samanya.

\section{KESIMPULAN}

Berdasarkan hasil analisis data dan pembahasan diatas dapat disimpulkan

1. Ada pengaruh secara simultan literasi ekonomi, status sosial orang tua dan kelompok teman sebaya terhadap pola konsumsi siswa

2. Ada pengaruh secara parsial literasi ekonomi terhadap pola konsumsi siswa

3. Ada pengaruh secara parsial status sosial orang tua terhadap pola konsumsi sisw

4. Ada pengaruh secara parsial kelompok teman sebaya terhadap pola konsumsi siswa.

\section{DAFTAR PUSTAKA}

Alam S, 2013. EkonomiUntuk SMA/MAKelas X. Jakarta: Erlangga

Anwar, Perabu Mangkunegara.2009. Perilaku Konsumsi. Bandung:Penerbit Refika Aditama

Desmita. 2010. Psikologi Perkembangan Peserta Didik. Bandung : Rosdakarya

Haryono, A. 2008. “Pengaruh Proses Pembelajaran, Penilaian Hasil Belajar dan Status Sosial Ekonomi terhadap Tingkat Economic Literacy Siswa SMA di Kota Malang” Disertasi Malang : PPS $\mathrm{UM}$ 
Hanifah, Nur. 2015. “Pengaruh Minat Belajar, Lingkungan Teman Sebaya dan Persepi Siswa Tentang Metode Mengajar Guru Terhadap Prestasi Belajar Pengantar Akuntansi Keuangan Siswa Kelas X SMK Negeri 1 Bantul. Tahun Ajaran 2014/2015" Skripsi Tidak Diterbitkan Yogyakarta: Fakultas Ekonomi Unversitas Yogyakarta.

Hasan, Ali. 2014. Marketing dan Kaus-Kasus Pilihan. Buku 1 Cetakan kedua

Januar, Kustiandi,. 2011. Beberapa Kajian Teori Kawasan Pendidikan Ekonomi. Malang PPS UM Mappiare, Andi \& Murizal. 2012.Psikologi Remaja. Surabaya: Usaha Nasional.

Prasetyo, RA. 2013. Pengaruh Status Sosial Ekonomi, Literasi Ekonomi, Dan Modernitas Siswa Terhadap Pola Konsumsi Siswa Kelas XI IPS SMA Negeri 1 Talun dengan Blitar". Skripsi Tidak Diakses Universitas Negeri Malang. UM.

Poerwo, Darminto. 2008. Kamus Umum Bahasa Indonesia. Jakarta: Balai Pustaka

Sina, peter garlans. 2012. Analisis literasi ekonomi. Jurnal economia alumni magister manajemen ukswsalatiga.volume 8, nomor 2, (http://journal.uny.ac.id/index .php) , diunduh 16 februari 2016

Soekanto, Soerjono. 2012. Sosiologi suatu pengantar. Jakarta: raja grafindopersada

Sumarwan, Ujang. 2011. Perilaku Konsumen Teori Dan Penerapannya Dalam Pemasaran. Bogor: Ghalia Indonesia.

Schifman, dkk. 2013. Perilaku Konsumen dan Strategi Pemasaran. Jilid 1.

Yulia, Fatma. 2010. Pola Konsumsi, Gaya Hidup, Indeks Masa Tubuh. Yogyakarta : UGM. 